\title{
VAD BEGRIPA ICKE KULTURVÅRDARNA?
}

Vad begripa icke filosoferna? - en rask sälles liv skrev en gång CJL Almqvist. Hans fråga skulle idag kunna parafraseras Vad begripa icke kulturvårdarna? - det raska folkets minneskultur.

Pratet om kulturarv har nu gått så långt och nått så högt att det föranlett den nationella kulturvårdsmyndigheten att ge sig uppdraget att utforma en nationell kulturarvsagenda för de tilltänkta kulturarvingarna och deras förmyndare. Arvs(ärftlighets?)lagarna ska ses över i ljuset av en landsomfattande utfrågning, i en 'medborgardialog' med ännu levande kulturbärare. Antikvarierna mobiliseras; det liknar misstänkt uppdraget till rikets antikvarier och hävdasökare 1630 även om memorialet 2001 ersatts av en matris. Kanske skulle man kunna eliminera alla de arvstvister som numera gör sig gällande och inte minst skymtat i denna tidskrifts artiklar genom åren? Har kulturvårdarna misslyckats med att lära känna den värld och de människor som de verkar bland?

Vad blev det av dem - de 'barfotaantikvarier' som vi drömde om och ville utbilda, den nya antikvariegeneration som skulle öppna närmuseer i kulturens fattigkvarter, verka i ständig medmänniskodialog och med vidöppna ögon mot omvärlden?

Kulturarvsdiskursen ägnas i föreliggande nummer fortsatt och vederbörlig uppmärksamhet. Richard Pettersson med uppdraget att utröna minnesvårdens värdegrunder skisserar sina grundfrågor kring kulturella arv och kollektiva minnen. Hans text får en kommentar i numrets klassikertext - utdraget ur Sverker Jansons Kulturvård och samhällsbildning, som introduceras av Erik Hofrén. Sverker Sörlin och Christer Nordlund pläderar för en nödvändig revision av den nationella landskapsbildens klichéer för att ge plats åt industrialismens och modernismens verkligheter. De besannar Sverker Jansons insikt att "motsättningen mellan gammalt och nytt är skenbar, då dagens samhällsprodukter i morgon är kulturminnen". Kulturarvet på individnivå får slutligen en kanske överraskande belysning i Veera Rautavuomas analys av Kate Atkinsons roman 'Behind the Scenes of the Museum'.

Numrets inledande fyra uppsatser rör sig om det återkommande ämnet utställningar. Lennart Palmqvist lyfter fram begreppet 'utställningskonst' och söker bakgrunden till utställningarnas formförändringar under förra seklet särskilt i impulser 
från konstutställandets utveckling från sekelskiftet 1900 och framåt. Han argumenterar vidare för den föremålscentrerade utställningen som museets specifika förmedlingsform, men framhåller att den måste bejaka en 'föremålsrelativiserad' modell. Simon Glinvad Nielsen ser fram mot de utställningspråk som ska kunna förverkligas i det utopiska Eyebeam-projektet i New York. Bruno Ingemann har i tidigare artiklar (1999/1 och 2000/1) redovisat studier av utställningsbesökare. Han beskriver nu två besökare i en konstutställning. Vibekke Vange och Ellen Marie Beck rapporterar från en utställningskurs i Museumshøjskolen år 2000 och pekar på att impulser till förnyelse av utställningsmediet kan hämtas också från filmkonsten.

Som en bro mellan utställning och kulturarv får John Aage Gjestrums postumt publicerade bidrag tjäna. Det handlar om John Aages sista projekt i Norge, Ivar Aasen-tunet. Ottar Grepstad har sammanställt utdrag ur rapporter och promemorior som skrevs av John Aage under förverkligandet av detta nya museum, ritat av arkitekten Sverre Fehn och beläget på en kulturminnesplats, ett projekt som även innebar den svåra utmaningen att göra en utställning om en abstraktion - det talade och skrivna språket.

Notiser har inte förekommit i tidskriften på länge. Redaktionen vill göra bättring och ber om bidrag. Denna gång ges plats åt de eftertankar som museikonferensen 'Museum 2000' i Stockholm förra året ingivit David Goa och åt tre bokrecensioner. Av dem anknyter Eva Perssons tankar om Julian Spaldings 'The Poetic Museum' till vårt inledande utställningstema.

Slutligen gläder sig redaktionen åt den svenska kulturministerns tappra utspel nyligen om gratis entré i statliga museer trots ett par mäktiga museichefers uttalade motvilja. På det elektroniska 'Museipedagogiskt forum' skriver Helena Friman upprörd: "Futtigt och eländigt klingar de i en tid då museer och allt det museer arbetar med skulle kunna spela en stor och viktig roll. Lyckligtvis finns det museichefer, för att inte tala om intendenter, pedagoger och andra museiverksamma, som vill bryta museernas elitstämpel och arbetar medvetet och offensivt med ett folkbildningsmål för ögonen.” 